В.П. Галенко, О.А. Страхова, С.I. Файбушевіча. СПб. 1999.

7 Ансофф I. Нова корпоративна стратегія / I. Ансофф. СПб. 1999.- С 416

8 Якушев А.В. Залучення та набір персоналу через систему Інтернет/ А.В. Якушев/ Управління персоналом. - 2008. №12. - C. 47-50.

9 Барнетт Д. Формулирование стратегии // Д. Барнетт, У. Уилстед. Проблемы теории и практики управления. 1992.- № 1.- C. 118-127.

10 Mason L. Strategic Planning for human Resources Management / L. Mason. Calgary. Alberta. 2003.

11 Хміль Ф.I. Управління персоналом: підручник для студентів вищихнавчальних закладів/ Ф.І. Хміль. К.: Академвидав, 2006. -488 с.

12 Глазов М.M. Управление персоналом: анализ и диагностика персонал-менеджмента: учебник / M.M. Глазов, И.П. Фирова, О.Н. Истомина. СПб.: ООО«Андреевский издательский дом», 2007. - 252 с.

13 Дуракова И.Б. Управление персоналом: учебник/ И.Б. Дуракова. М.: ИНФРА-М, 2010. - 572 c.
14 Bertchel O. Personal-Management / O. Bertchel. - Stutgart, 2003. - 544 p.

15 Клейнер Г.Б. Кадровая стратегия предприятия: систематизация и основные варианты/ Г.Б. Клейнер// Труды ольного экономического общества. - 2009. - Том № 125. - М.: ЭО. - Режим доступа: http://www.kleiner.ru/arpab/kadrstr.html

16 Криворучко О.М. Класифікація стратегій управління персоналом підприємства/ О.М. Криворучко, Т.О. одолажська// Економіка транспортного комплексу: зб. наук. праць. - Х.: ХНАДУ, 2011. - ип. 18. - С. 59-68.

17 Хандій О.О. Управління персоналом підприємства: концептуальне визначення та механізми розвитку : монографія / О.О. Хандій. - Луганськ: вид-во СНУ ім. В. Даля, 2010. - 240 с.

18 Морщенок Т.С. Стратегічні напрями удосконалення управління персоналом: автореф. дис... канд. екон. наук: 08.00.04 / Т.С. Морщенок; Приазов. держ. техн. ун-т. - Маріуполь, 2008. - 19 с. - укр.

УДК 336.74(477)

\title{
СУЧАСНИЙ СТАН ОБЛІКУ ЗАПАСІВ В УКРАЇНІ: ПРОБЛЕМИ ТА ШЛЯХИ ВДОСКОНАЛЕННЯ
}

\author{
Орлова В.М., к.е.н., доцент, \\ Кокошвілі Д.Р., магістр (УкрДУЗТ)
}

У статті розглянуто важливість забезпечення раціонального використання запасів для підприємства. Досліджено сучасний стан обліку господарських операчій, пов'язаних з організацією та здійсненням обліку запасів на підприємстві, $i$ запропоновано напрями їх удосконалення. Розроблено конкретні шляхи удосконалення процесу використання запасів, зокрема представлено механізм оптимізації обліку запасів. Проаналізовано основні проблеми, пов'язані з організащією та веденням обліку запасів на підприємствах, та запропоновано напрямки їх удосконалення.

Ключові слова: запаси, механізм оптимізації, раціональне використання, облік запасів, підприємство, господарський процес.

(C) Орлова В.М., Кокошвілі Д.Р.
Вісник економіки транспорту і промисловості № 60, 2017 


\title{
СОВРЕМЕННОЕ СОСТОЯНИЕ УЧЕТА ЗАПАСОВ В УКРАИНЕ: ПРОБЛЕМЫ И ПУТИ УСОВЕРШЕНСТВОВАНИЯ
}

\author{
Орлова В.Н., к.э.н., доцент, \\ Кокошвили Д.Р., магистр (УкрГУЖТ)
}

В статье рассмотрена важность обеспечения ращионального использования запасов для предприятие. Исследовано современное состояние учета хозяйственных операций, связанных с организаџией и осуществлением учета запасов на предприятие, и предложены направления их усовершенствования. Разработаны конкретные пути усовершенствования прочесса использования запасов, а именно представлено механизм оптимизации учета запасов. Проанализированы основныле проблемы, связанные с организаџией и ведением учета запасов на предприятиях, и предложены направления их решения.

Ключевые слова: запасы, механизм оптимизации, рациональное использование, учет запасов, предприятие, хозяйственный процесс.

\section{CURRENT STATUS OF ACCOUNTING OF INVENTORIES IN UKRAINE: PROBLEMS AND WAYS OF IMPROVEMENT}

\author{
Orlova V.M., Candidate of Economic Sciences, associate professor, \\ Kokoshvili D.R., master (USURT)
}

In the article the importance of optimal number of inventories for the enterprise.

Ukraine is in the process of market conditions improvement that requites radical changes in the functioning of the economic mechanism and harmonizing the interests of everybody involved. The overall results of the company depend on how effectively the existing inventories are used. Market economy is an incentive to introduce new techniques and technológ'cs, it broadens the possibilities of using new financial instruments and mechanisms, but in practice there is a problem about the reality of their application. Researched the current state accounting of business transactions related to the Organization and implementation of inventories accounting in enterprises directions of improving them. Analysed the main problems related to the Organization and conduct of the inventories accounting at enterprises and the directions of their decision. The modern range of problems over of the optimal use of productive supplies of inventories is brought. Concrete ways are worked out for the improvement of process of the use of productive supplies. Mechanism of optimization of account of supplies presented in particular. As a chart the unfolded structure over of ways of improvement of account of productive supplies is brought.

Key words: inventories, optimization mechanism, rational use, reserves accounting, company, economic process, economy.

Постановка проблеми та іiі зв'язки 3 науково-практичними чи теоретичними завданнями. Для здійснення виробничо-господарської діяльності підприємствами всіх форм власності та галузей економіки використовуються запаси, які $є$ найбільш важливою і значною частиною активів підприємства. Добре побудований, належним чином організований облік запасів, тобто якісна інформація про їх наявність та рух, мають суттєве значення в

Вісник економіки транспорту і промисловості № 60, 2017 
управлінні господарською діяльністю кожного підприємства.

Аналіз останніх досліджень i публікацій. Вагомий внесок у дослідження проблем обліку запасів зробили такі вітчизняні науковці, як О.А. Бакурова [1], О.І. Коблянська [2], К.С. Нагірська [3], Л.В. Нападовська, [4], М.Ф. Огійчук [5], О.Д. Вовчак [6] та ін. Однак вивчення наукових праць свідчить про те, що й досі залишаються дискусійними теоретичні положення i важливі питання обліку запасів.

Мета роботи полягає у вивченні теоретичного та практичного досвіду організації бухгалтерського обліку запасів та розробці шляхів його удосконалення. Для досягнення поставленої мети необхідно виконати наступні завдання: дослідити питання визначення терміну «запаси»; вивчити склад та класифікацію запасів; оцінка та методи обліку запасів; сучасний стан синтетичного та аналітичного обліку.

Виклад основного матеріалу дослідження. Головною передумовою успішного здійснення господарського процесу як основної ланки діяльності підприємств $є$ наявність та раціональне використання запасів.

Відповідно до П(С)БО 9, що максимально відображає МСФО 2 «Запаси», запаси - це активи, які:

- утримуються для подальшого продажу (розподілу, передачі) за умов звичайної господарської діяльності;

- перебувають у господарському процесі з метою подальшого споживання;

- утримуються для споживання під час діяльності, виконання робіт та надання послуг, а також управління підприємством [7].

Запаси (сировина, матеріали, паливо i т. д.) $€$ предметами, на які спрямована праця людини 3 метою одержання миттевого використання. На відміну від засобів праці, які зберігають у господарському процесі свою форму i переносять вартість на продукт поступово, предмети праці споживаються повністю і повністю переносять свою вартість на цей продукт i заміняються після кожного операційного циклу.

На сучасному етапі йде тенденція прискорення оборотності запасів на підприємстві, а отже, і зниження розмірів запасів, але вони, як і раніше, займають головне місце у забезпеченні підприємства нормальними умовами роботи. На рівні фірм запаси відносяться до складу об'єктів, що вимагають великих капіталовкладень, і тому являють собою один із факторів, що визначають політику підприємства i впливають на рівень обслуговування в цілому. Тому важливо розглянути класифікацію запасів, що представлена в таблиці 1.

Багато підприємств не приділяють йому належної уваги i постійно недооцінюють свої майбутні потреби в наявних запасах. У результаті цього вони зазвичай зіштовхуються 3 тим, що їм приходиться вкладати в запаси більший капітал, чим передбачалося.

$\mathrm{y}$ той же час, залишаються невирішеними питання вдосконалення документації оперативного та аналітичного обліку запасів, особливо нагальною постає проблема автоматизації ïx обліку. Вирішення цих питань полягає в розробці основних напрямів і конкретних рекомендацій 3 удосконалення методики обліку запасів, в їх оцінці при вибутті, методики проведення аналізу ефективного використання запасів, а також посиленні інформаційної та контрольної функцій обліку в управлінні виробництвом. Для вирішення зазначених проблемних аспектів необхідно вирішити наступні завдання, що представлені на рис. 1. 
Класифікація запасів

\begin{tabular}{|c|c|c|c|}
\hline \begin{tabular}{l|} 
No \\
II \\
$/$ \\
II
\end{tabular} & $\begin{array}{l}\text { Класифікація } \\
\text { групи за } \\
\text { призначенням }\end{array}$ & Вид запасів & Характеристика \\
\hline \multirow{2}{*}{1} & \multirow{2}{*}{$\begin{array}{c}\text { За } \\
\text { призначенням і } \\
\text { причинами } \\
\text { утворення }\end{array}$} & Постійні & \begin{tabular}{lll} 
Частина запасів, що & \multicolumn{2}{c}{ забезпечують } \\
безперервність виробничого & процесу \\
двома черговими поставками & & \\
\end{tabular} \\
\hline & & Сезонні & $\begin{array}{lcll}\text { Запаси, що утворюються } & \text { при } & \text { сезонному } \\
\text { виробництві продукції } & \text { чи } & \text { сезонному } \\
\text { транспортуванні } & & \end{array}$ \\
\hline \multirow{3}{*}{2} & \multirow{3}{*}{$\begin{array}{c}\text { За місцем } \\
\text { знаходження }\end{array}$} & Складські & $\begin{array}{l}\text { Запаси, що знаходяться } \\
\text { підприємства }\end{array}$ \\
\hline & & У виробництві & Запаси, що знаходяться в процесі обробки \\
\hline & & В дорозі & $\begin{array}{l}\text { Продукція, що відвантажена споживачу і ще } \\
\text { ним не отримана, знаходиться в дорозі }\end{array}$ \\
\hline \multirow[t]{2}{*}{3} & \multirow[t]{2}{*}{$\begin{array}{c}\text { За рівнем } \\
\text { наявності на } \\
\text { підприємстві }\end{array}$} & Нормативні & 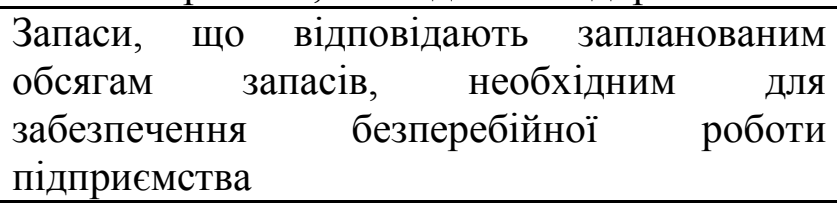 \\
\hline & & Понаднормові & $\begin{array}{l}\text { Запаси, що перевищують їх нормативну } \\
\text { кількість }\end{array}$ \\
\hline \multirow{2}{*}{4} & \multirow{2}{*}{$\begin{array}{c}\text { За наявністю на } \\
\text { початок і кінець } \\
\text { звітного } \\
\text { періоду }\end{array}$} & Початкові & $\begin{array}{l}\begin{array}{l}\text { Величина запасів } \\
\text { періоду }\end{array} \\
\end{array}$ \\
\hline & & Кінцеві & Величина запасів на кінець звітного періоду \\
\hline \multirow[b]{2}{*}{5} & \multirow[b]{2}{*}{$\begin{array}{l}\text { По відношенню } \\
\text { до балансу }\end{array}$} & Балансові & $\begin{array}{l}\text { Запаси, що є власністю підприємства i } \\
\text { відображаються в балансі }\end{array}$ \\
\hline & & Позабалансові & $\begin{array}{l}\text { Запаси, що } \\
\text { не } \text { належать підприємству i } \\
\begin{array}{l}\text { знаходяться } \\
\text { обставини }\end{array} \\
\text { ньому через визначені }\end{array}$ \\
\hline \multirow[t]{2}{*}{6} & \multirow{2}{*}{$\begin{array}{c}\text { За ступенем } \\
\text { ліквідності }\end{array}$} & Ліквідні & $\begin{array}{lllll}\text { Запаси, } & \text { що легко перетворюються на } \\
\text { грошові } & \text { кошти } & \text { у короткий термін } & \text { без } \\
\text { значних } & \text { витрат } & \text { первісної вартості таких } \\
\text { запасів } & & & & \end{array}$ \\
\hline & & Неліквідні & $\begin{array}{l}\text { Виробничі та товарні запаси, які неможливо } \\
\text { легко перетворити на грошові кошти у } \\
\text { короткий термін }\end{array}$ \\
\hline \multirow{2}{*}{7} & \multirow{2}{*}{$\begin{array}{c}\text { За } \\
\text { походженням }\end{array}$} & Первинні & $\begin{array}{l}\text { Запаси, що надійшли на підприємство від } \\
\text { інших підприємств і не підлягли обробці на } \\
\text { підприємстві }\end{array}$ \\
\hline & & Вторинні & $\begin{array}{l}\text { Матеріали і вироби, що після первинного } \\
\text { використання можуть застосовуватись } \\
\text { вдруге на підприємстві (відходи) }\end{array}$ \\
\hline
\end{tabular}

Вісник економіки транспорту і промисловості № 60, 2017 


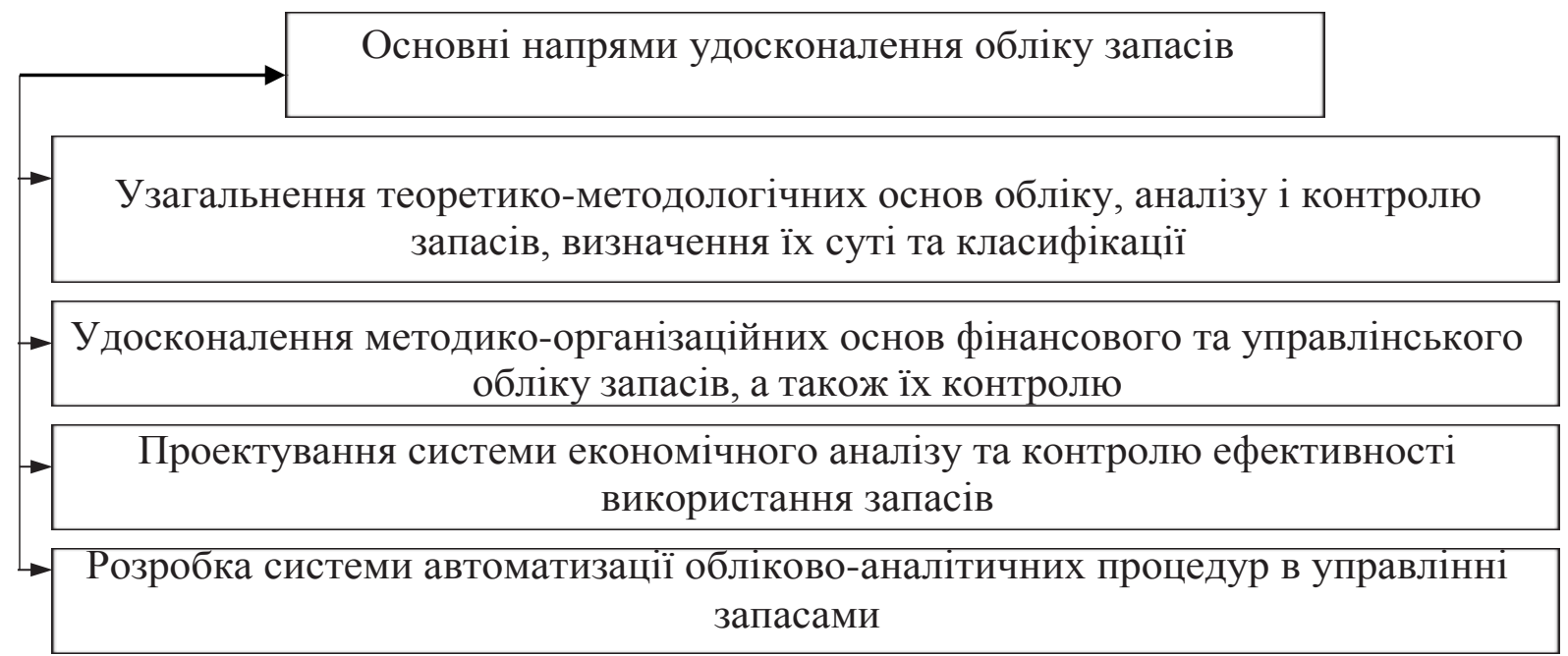

Рис. 1. Напрямки удосконалення обліку запасів [8]

Поліпшенню обліку запасів сприяє впорядкування первинної документації, широке впровадження типових уніфікованих форм, підвищення рівня автоматизації обліково-обчислювальних робіт, забезпечення строгого порядку приймання, зберігання й витрат сировини, матеріалів, комплектуючих виробів тощо.

Необхідно також упроваджувати ефективні форми попереднього й поточного контролю дотримання норм запасів і витрат матеріальних ресурсів, приділяти більше уваги підвищенню вірогідності оперативного обліку руху напівфабрикатів, комплектуючих виробів, деталей i вузлів у господарстві. Дані бухгалтерського обліку повинні містити інформацію для знаходження резервів зниження собівартості продукції в частині раціонального використання матеріалів, зниження норм витрат, забезпечення належного зберігання.

Спираючись на вищевикладене, вважаю, що процесу оптимізації обліку запасів, a також поліпшенню їх використання має сприяти не тільки якісно складена документація, а й ефективна дія 3 аналізу та організації обліку.

Обираючи методи обліку запасів, слід пам'ятати, що зміна облікової політики повинна бути обгрунтованою i можлива лише у тому випадку, коли така зміна буде найбільш повно і достовірно відображати специфіку діяльності підприємства (оскільки причини їі зміни згідно 3 вимогами П(С)БО вказуються у примітках до звітності, а якщо і не вказуються, то саме існування змін може насторожити користувачів). До того ж на підприємстві можуть застосовуватись різні методи оцінки для різних груп запасів. В момент придбання запаси обліковуються за початковою вартістю. Методи оцінки запасів застосовуються для визначення собівартості запасів, що списуються, i не впливають на їх початкову вартість. Проте П(С)БО 9 вказує на необхідність відображення у балансі запасів за найменшою 3 двох оцінок - початкової вартості або чистої вартості реалізації.[9] Очевидно, що така вимога покликана необхідністю застосування принципу обачності, відповідно до якого активи або дохід не повинні бути завищеними, а зобов'язання або втрати - заниженими. Виникає новий термін - чиста вартість реалізації запасів.

Чиста вартість реалізації запасів це сума, яку очікується отримати при реалізації запасів в умовах звичайної діяльності: за вирахуванням ймовірних витрат на завершення виробництва запасів i ïx реалізацію. Це означає, що чиста вартість реалізації відповідає ринковій вартості запасів та застарілих i

Вісник економіки транспорту і промисловості № 60, 2017 
ушкоджених ТМЦ за мінусом витрат, яких підприємство зазнає у процесі підготовки їх до реалізації, а також безпосередньо при реалізації. Запаси часто мають чисту реалізаційну вартість набагато нижчу за їх початкову вартість. Проте подібна ситуація може виникнути не обов'язково при пошкодженні ТМЦ. Швидкі технологічні зміни сприяють швидкому моральному старінню активів. Вимога відображення у звітності запасів за найменшою 3 початкової i ринкової вартості базується на припущенні, що якщо ціна товару впала, то, відповідно, знизиться і його продажна вартість. Проте запаси можуть уцінюватися не тільки у зв'язку із втратою первинної якості. Запаси повинні бути уцінені і відображені в обліку та звітності за чистою вартістю реалізації у випадку, якщо на дату складання балансу знизилась ціна їх реалізації. Уцінка запасів буде проводитися також у випадку, якщо зросли очікувані витрати на їх збут. Чиста вартість реалізації повинна визначатися за кожною одиницею (тобто однорідною групою) запасів шляхом вирахування, як уже зазначаюся вище, 3 очікуваної ціни реалізації очікуваних витрат на завершення виробництва та збут. Таким чином, переоцінка запасів повинна проводитися на дату складання балансу. Оскільки така переоцінка потребує досить значних затрат часу, то здійснення іiі поквартальне не має сенсу, тому доцільно проводити таку переоцінку по закінченні календарного року (при складанні річної звітності). У зазначений термін підприємство проведе інвентаризацію. Ті запаси, яких немає у наявності, будуть списані з балансу як неіснуючі і віднесені на витрати поточного року, а за запасами, що залишились, повинна проводитися відповідна переоцінка [10].

Спрощення оформлення операцій, пов'язаних 3 рухом запасів, дозволить стежити за ретельним i своєчасним проведенням інвентаризації та удосконалити

методологію

бухгалтерського обліку, що дозволить розпланувати будівництво складських приміщень у достатній кількості, а також визначити оптимальну потребу у запасах та їх раціональному використанні [11].

Значно поліпшити організацію обліку запасів можна, удосконалюючи процес документування, тобто ширше використовуючи накопичувальні документи (лімітно-забірні картки, відомості тощо), картки складського обліку як витратний документ по відпущених матеріалах (бездокументальну систему оформлення витрат матеріалів).

Для вдосконалення обліку запасів доцільне також використання на всіх ділянках обліку уніфікованих форм документації. Крім того, необхідною умовою також є:

- створення

графіків

документообігу 3 обліку запасів i доведення до виконавців їх функцій при створенні i перевірці первинного документа;

- видача розпорядчої документації особам, що відповідають за здійснення тієї або іншої господарської операції і мають право підпису первинних документів; контроль із боку працівників бухгалтерії правильності оформлення первинної документації з обліку запасів (включення в обов'язок бухгалтера, що робить обробку документа, цієї функції через посадові інструкції та встановлення відповідальності за її недотримання) [12].

Висновки. Таким чином, реалізація перелічених напрямів удосконалення обліку запасів призведе до значного підвищення результативності та фінансово-економічної діяльності підприємств, а також дозволить налагодити більш дієвий i менш трудомісткий облік, контроль наявності, руху i використання запасів, а також досягти їх економії. 
ПЕРЕЛІК ВИКОРИСТАНИХ ДЖЕРЕЛ

1.Шерстюк О. О. Оцінювання системи внутрішнього контролю / О. О. Шерстюк, О. А. Бакурова // Економічні науки. Сер. : Облік і фінанси. - 2013. - Вип. 10(4). - C. 413-420.

2.Коблянська O.I. Бухгалтерський i податковий облік фінансових кредитів. 2013. - № 2. - C. 246-251.

3.Нагірська К.С. Принципи та вимоги до формування звітності підприємств: управлінський аспект. / К.Є.Нагірська, Я.С. Герус - 2013. - Вип. 10(2). - C. 176-183.

4.Нападовська Л.В. Базові принципи управлінського обліку. / Нападовська Л.В. - C. 173-181.

5.Огійчук М.Ф. Фінансовий та управлінський облік за національними стандартами: Підручник / За ред. проф. М. Ф. Огійчука. - 6-те вид., перероб. і допов. К. : Алерта, 2011. - 1042 с.

6.Вовчак О.Д. Фінансовий аналіз. / О.Д.Вовчак, Н.І.Власюк, Р.С. СорокаЛьвів: Львів. комерц. акад., 2002. - 96 с.

7.Положення

(стандарт) бухгалтерського обліку 9 «Запаси»: Наказ
Міністерства фінансів України від 20.10.99 p. № 246, зі змінами та доповненнями. [Електронний ресурс] - Режим доступу: http://zakon2.rada.gov.ua/laws/show/z075199/ed20120527

8.Бутинець Ф.Ф. Економічний аналіз: [навч. посіб. для студ. вищ. навч. закл., спец. 7.050106 «Облік і аудит»] / Бутинець Ф.Ф.. - Житомир: Рута, 2003. $680 \mathrm{c}$.

9.Кузнецова М.А. Тенденции и закономерности управления запасами / M. Кузнецова // Проблемы теории и практики управления (рус.). - 2009. - № 11. - С. $63-$ 72.

10. Орлов О.О. Планування діяльності підприємства: [підручник] / О.О. Орлов. - К.: Скарби, 2002. - 336 с.

11. Закон України «Про бухгалтерський облік та фінансову звітність в Україні» № 996 - ХІY ВР від 16 липня 1999 p.

12. Павлюк I. Проблеми бухгалтерського обліку виробничих запасів, товарів та пропозиції щодо їх вирішення / I. Павлюк // Бухгалтерський облік і аудит (укр.). - 2010. - № 6. - С. 40 57.

\section{УДК 658.012.8}

\section{ПІДХОДИ ДО ПОБУДОВИ ФУНКЦІОНАЛЬНОЇ СТРУКТУРИ ЗАБЕЗПЕЧЕННЯ ЕКОНОМІЧНОЇ БЕЗПЕКИ ПІДПРИЕМСТВ МАШИНОБУДУВАННЯ}

\section{Писаревський М. І., аспірант (ХНУМГ імені О.М. Бекетова)}

В роботі вирішено завдання синтезу функиіональної структури для реалізації механізму забезпечення економічної безпеки в напрямку протидії рейдерству, щцо передбачає: побудову та розбиття графа взаємозв'язку завдань на мінімально зв'язані підграфи; виділення функціональних блоків на підставі групування завдань $з$ використанням методів кластеризації. В результаті проведеного дослідження типова організаиійна структура департаменту безпеки підприємства машинобудування доповнена відділеннями та групами у напряму протидї рейдерству. 